5." MPEETED BY TIC MAY $8 \quad 1973$

This is an informal report intended primarily for internal or

UCID - 16243

limited external distribution. (The opinions and conclusions stated are those of the author and may or may not be those of the laboratory.)

\author{
㢟 \\ LAWRENCE LVERMORE LABORATORY \\ University of California/Livermore, California
}

\title{
PERMEABILITY OF MESAVERDE SANDSTONE SAMPLES: \\ PROJECT RULISON
}

R. Quong

March 1, 1972

This document is

PUBLICLY RELEASABLE

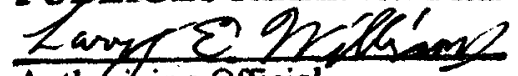

Authrorizing Official

Date: $01 / 04 / 20106$

\section{NOTICE}

This report was prepared as an account of work sponsored by the United States Government. Neither the United States nor the United States Atomic Energy Commission, nor any of their employees, nor any of their contractors, subcontractors, or their employees, makes any warranty, express or implit:d, or assumes any

legal liability or responsibility for the accuracy, com.

pleteness or usefulness of any intormation, apparatus,

pleteness or usefulness of any intormation, apparatus,
product or process disclosed, or represents that its use

would not infringe privately owned rights.

\section{Ha OUASSIFIED}

DIVISION OF CLASSIFICATION

BY I.L.CUCChiarg WER

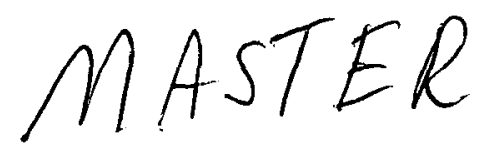

Sologis

Prepared for U. S. Atomic Energy Commission under contract no. W: $7405-$ Eng-48 


\section{DISCLAIMER}

This report was prepared as an account of work sponsored by an agency of the United States Government. Neither the United States Government nor any agency Thereof, nor any of their employees, makes any warranty, express or implied, or assumes any legal liability or responsibility for the accuracy, completeness, or usefulness of any information, apparatus, product, or process disclosed, or represents that its use would not infringe privately owned rights. Reference herein to any specific commercial product, process, or service by trade name, trademark, manufacturer, or otherwise does not necessarily constitute or imply its endorsement, recommendation, or favoring by the United States Government or any agency thereof. The views and opinions of authors expressed herein do not necessarily state or reflect those of the United States Government or any agency thereof. 


\section{DISCLAIMER}

Portions of this document may be illegible in electronic image products. Images are produced from the best available original document. 


\title{
PERMEABILITY OF MESAVERDE SANDSTONE SAMPLES: \\ PROJECT RULISON
}

\begin{abstract}
The permeability (K) of preshot Rulison samples was measured as a function of net confining pressure. These sandstone samples represent gas-bearing sands located at a depth of $\sim 8400 \mathrm{ft}$. The measurements were made for comparative studies with measurements and calculations from other sources.
\end{abstract}

\section{EXPERIMENTAL PROCEDURE}

Permeability measurements were conducted using equipment and techniques developed in previous studies with other sandstones. ${ }^{1,2}$ Current data acquisition is greatly facilitated through the partial use of a small computer control system which will eventually operate and control the permeability apparatus. Although computer control of the apparatus is not yet functional, the FOCAL programming routines, the signal converters for pressures and flow transducers, and the recording and output features of the system are usable.

For sample preparation, a 1 -in. diam $\times 1 \frac{1}{2}$-in. long cylindrical sample is removed from the field-retrieved core sample. The ends of the sample are faced off and attached to end adapters for tubing connection. A flexible plastic jacket is cast around the sample, which allows it to be submerged in an autoclave. Dry nitrogen is then passed axially through the sample while it is subjected to various confining hydraulic pressures. Appropriate pressure and flow measurements are taken. Net confining pressure (NCP), which is the oil pressure minus mean gas pressure, was varied from 300 to $9500 \mathrm{psi}$. The in situ NCP is $5250 \mathrm{psi}$. Sample water saturation at time of measurement varied from 12 to $17 \%$ of the void volume, compared with the in situ value of $50 \%$. Nitrogen gas pressures as high as 1250 psi were required to produce sufficient flow through the samples at the high confining pressures.

\section{RESULTS}

A linear reduction in $K$ to $30 \%$ of its initial value is observed as the NCP is increased to $3000 \mathrm{psi}$. Additional increase in NCP to 9500 psi reduces absolute permeability more slowly to about $5 \%$ of its initial value. The horizontally cut samples have higher K's than equivalent vertically cut samples. This reflects the geological conditions of the gas-bearing sands, perhaps to the orientation of bedding planes. 
Table 1. Permeability (K) of Rulison samples, unconfined and at 5250 psi.

\begin{tabular}{lcccc}
\hline \multicolumn{1}{c}{ Sample } & $\begin{array}{c}\text { Water } \\
\text { saturation, } \\
\text { of void } \\
\text { volume }\end{array}$ & $\begin{array}{c}\mathrm{K} \\
\text { (unconfined), } \\
\mu \mathrm{D}\end{array}$ & $\begin{array}{c}\mathrm{K} \\
\text { (at 5250 psi), } \\
\mu \mathrm{D}\end{array}$ & $\begin{array}{c}\mathrm{K} \text { (estimated, } \\
\text { at 5250 psi and } \\
50 \% \text { water } \\
\text { saturated), } \mu \mathrm{D}\end{array}$ \\
\hline 8400 hor & - & 25.0 & - & - \\
8400 vert & 16.9 & 7.7 & 1.4 & 0.3 \\
8404 hor & 12.0 & 21.3 & 2.5 & 0.4 \\
8404 vert & 12.2 & 16.5 & 1.8 & 0.3 \\
8404 (USBM $^{3}$ ) & 12.0 & 73.5 & 6.1 & 1.3 (measured) \\
8404 (Core & & & & - \\
Lab., Inc. ${ }^{4}$ ) & dry & 150 & - & - \\
\hline
\end{tabular}

Table 1 lists the values of $K$ at unconfined conditions and at an NCP of 5250 psi, which represents conditions at $8400 \mathrm{ft}$ where the sands are located. The percentage water saturation after sample measurement is also listed. The permeability at $50 \%$ water saturation is estimated from the experimental data and from the effect of water on permeability in similar studies with Gasbuggy sandstones. ${ }^{2}$

Figures 1-3 show the effect of confining pressure on permeability. Unconfined or initial permeability is the extrapolated value at zero confining pressure The secondary curves show the hysteresis effect with confining pressure. Recovery is gradual and only $80 \%$ complete after three days. Complete recovery is probably never attained, due to permanent deformation of the rock matrix. Figure 4 shows the "slip" contribution to permeability first noted by Klinkenberg, and hence the Klinkenberg correction to permeability for gas pressure. ${ }^{5}$ In these measurements the effect is small (Fig. 4), especially when compared with the normal spread in permeability measurements. Therefore, no corrections were made for slip.

As noted in Table 1 , the permeability results in this paper are considerably lower than those from other sources. The reasons are not obvious. Perhaps the effect of sample size is important. Infrequent but significant flow paths can be excluded in preparing a few small random samples. Insufficient sampling could then result in permeability values which deviate considerably from the mean.

Calculations based on production flow and well pressures by Montan ${ }^{6}$ indicate in situ $\mathrm{K}$ of $\sim 8 \mu \mathrm{D}$. This is considerably higher than any of the above sample measurements made at simulated in situ conditions. Measurements made for Project Gasbuggy produced similar results. That is, in situ $\mathrm{K}$ was $10 \mu \mathrm{D},{ }^{7}$ compared with $0.7 \mu \mathrm{D}^{2}$ estimated from laboratory measurements. In situ permeability is not unexpectedly higher, in that permeability based on in-place flow includes the effect of flow mechanisms on every scale within the reservoir, not just those restricted to small samples. In general, the Rulison samples are not appreciably different from Gasbuggy or Wagon Wheel sandstone samples in terms of both absolute permeability and permeability response to confining pressure. 


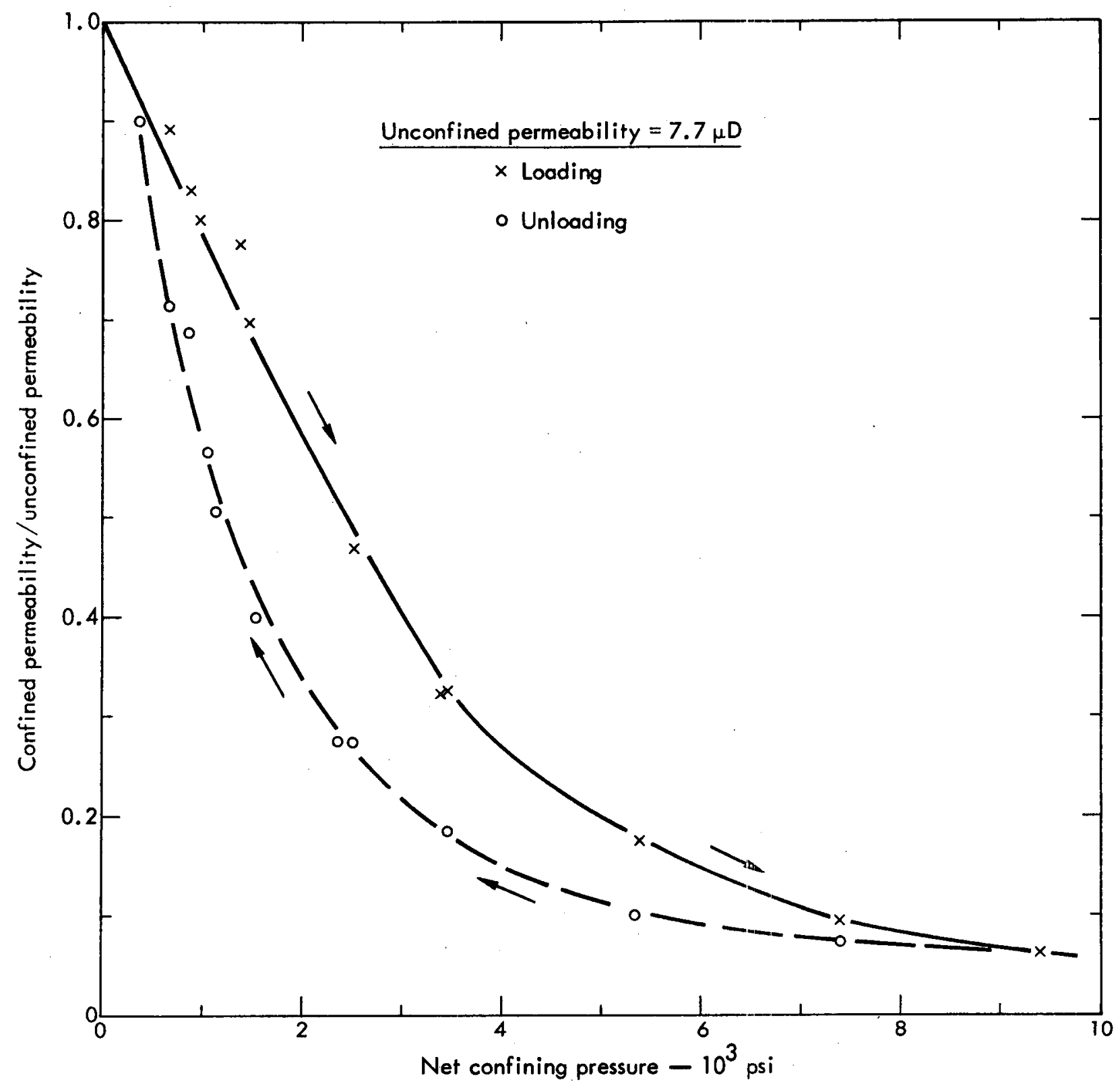

Fig. 1. Effect of net confining pressure on permeability for sample 8400 vert (Rulison). 


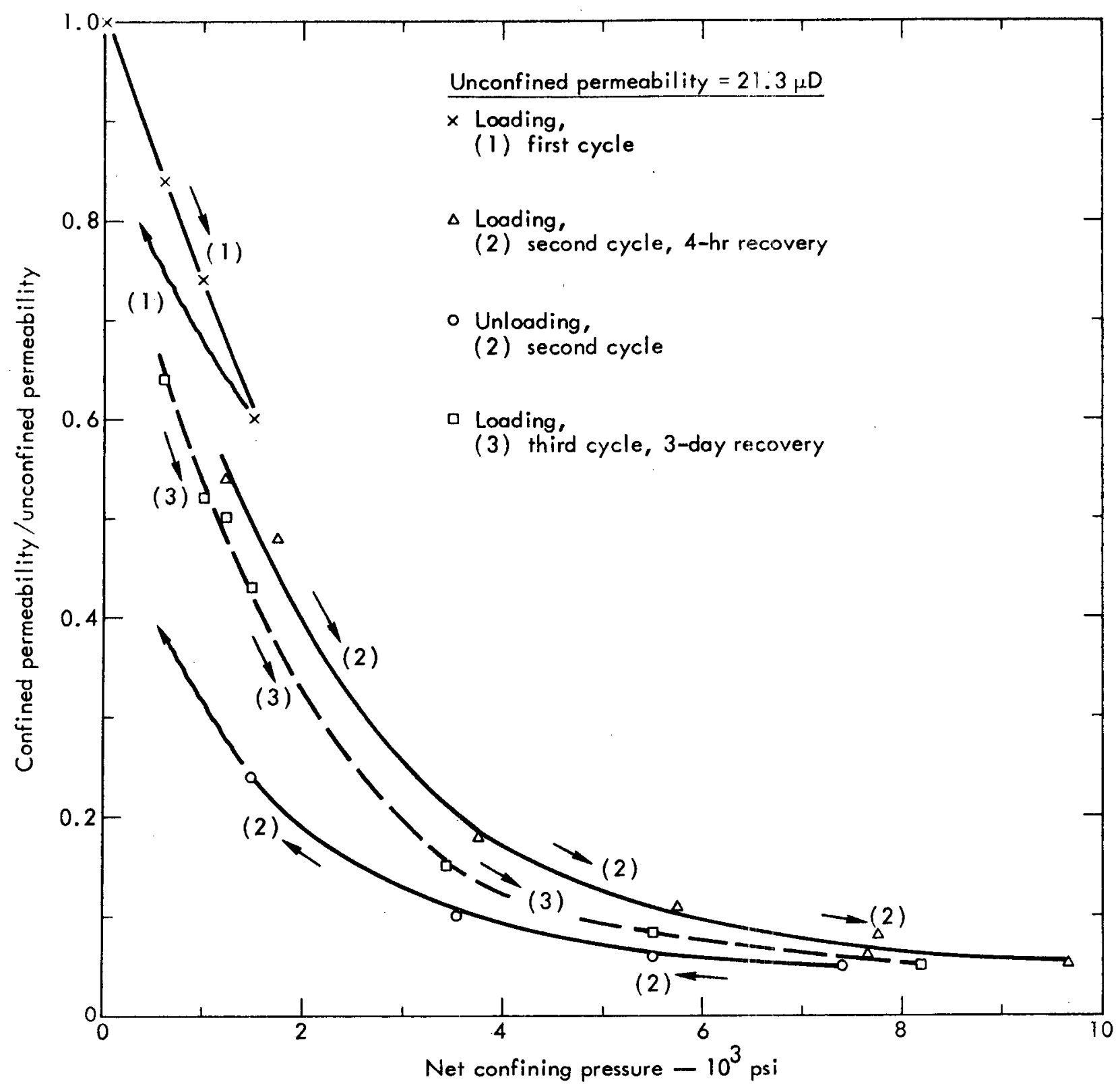

Fig. 2. Effect of net çonfining pressure on permeability for sample 8404 hor (Rulison). 


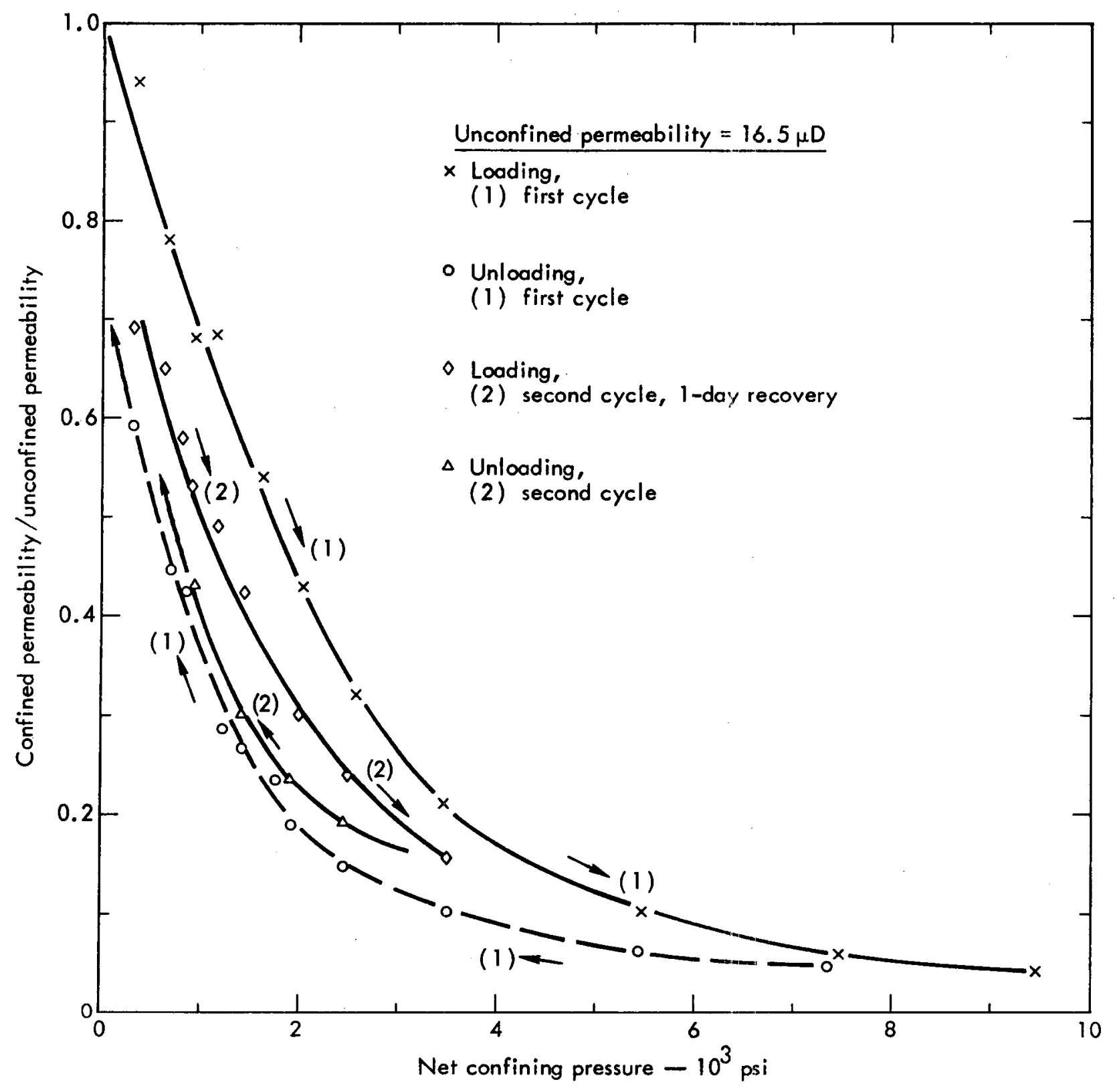

Fig. 3. Effect of net confining pressure on permeability for sample 8404 vert (Rulison). 


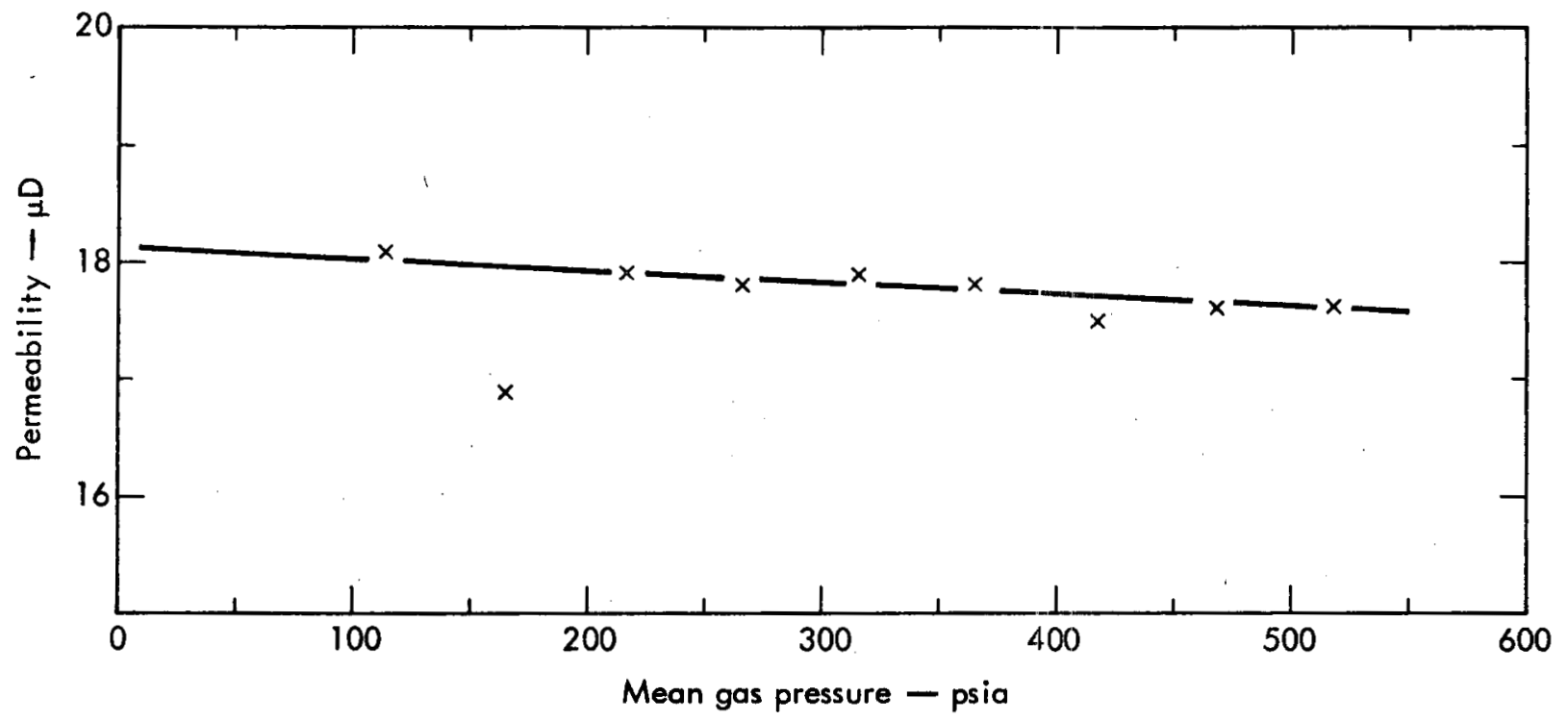

Fig. 4. Permeability at $600 \pm 4$ psi NCP as a function of mean dynamic gas pressure for sample 8404 hor (Rulison). 


\section{REFERENCES}

1. R. Quong and V. J. LaGuardia, Permeability of Gas Reservoir Specimens: Project Wagon Wheel, Lawrence Livermore Laboratory, Rept. UCID-15751 (1970).

2. R. Quong and V. J. LaGuardia, Permeability of Pictured Cliffs Sandstone: Gas buggy Preshot and Postshot Measurements, Lawrence Livermore Laboratory, Rept. UCRL-50946 (1970).

3. C. Atkinson, U.S. Bureau of Mines, private communication (1970).

4. Core Laboratories, Inc., Measurements for Austral Oil Co., private communication (Jan. 20, 1969).

5. R. E. Collins, Flow of Fluids Through Materials (Chapman and Hall, Ltd., London, 1961).

6. D. Montan, Lawrence Livermore Laboratory, private communication.

7. A. Holzer, Gasbuggy in Perspective, Lawrence Livermore Laboratory, Rept. UCRL-72175 (1970).

8. Technical Studies Report: Project Wagon Wheel, El Faso Natural Gas Company, Ed., PNE-WW-1 (1971). 
IfL Internal Distribution

TID Files

External Distribution

G. R. Luetkehans, CER Geonuclear Corp., Las Vegas, Nevada

"This report was prepared as an account of work sponsored by the United States Government. Neither the United States nisr the United States Atomic Energy Commission, nor any of their employees, nor any of their contractors, subcontractors, or their employees, makes any warranty, express or implied, or assumes any legal liability or responsibility for the accuracy, completeness or usefulness of any information, apparatus, product or process disclosed, or represents that its use would not infringe privatelyowned rights." 